\title{
Selaginellin A and B, Two Novel Natural Pigments Isolated from Selaginella tamariscina
}

\author{
Xian-Long ChEnG, ${ }^{a}$ Shuang-Cheng MA, ${ }^{*, a}$ Jian-Dong YU, ${ }^{a}$ Shi-Ying YANG,${ }^{b}$ Xin-Yue XIAO, ${ }^{a}$ \\ Jun-Ying Hu, ${ }^{a}$ Yang Lu, ${ }^{b}$ Pang-Chui SHaw, ${ }^{c}$ Paul Pui-Hay But, ${ }^{c}$ and Rui-Chao LiN ${ }^{a}$ \\ ${ }^{a}$ Department of Chinese Materia Medica and Natural Products, National Institute for the Control of Pharmaceutical \& \\ Biological Products; Beijing, 100050, P. R. China: ${ }^{b}$ Institute of Materia Medica, Chinese Academy of Medical Sciences \& \\ Peking Union Medical College; Beijing, 100050, P. R. China: and ${ }^{c}$ Institute of Chinese Medicine, The Chinese University \\ of Hong Kong; Shatin, Hong Kong, P. R. China.
}

Received October 31, 2007; accepted March 10, 2008; published online April 14, 2008

Two new unusual natural pigments were first isolated from the whole herbs of Selaginella tamariscina. The structure of selaginellin A (1) was established as $(R, S)-4-\left[\left(4^{\prime}\right.\right.$-hydroxy-3-((4-hydroxyphenyl)ethynyl)biphenyl-2yl)(4-hydroxyphenyl)methylene]-2,5-cyclohexadien-1-one and selaginellin $B$ (2) as $(R, S)-4-\left[\left(4^{\prime}\right.\right.$-methoxy-4(methyl)-3-((4-methoxyphenyl)ethynyl)biphenyl-2-yl)(4-methoxyphenyl)methylene]-2,5-cyclohexadien-1-one, along with four known biflavonoids, amentoflavone (3), hinokiflavone (4), heveaflavone (5), and 7"-O-methylamentoflavone (6). Their chemical structures were elucidated by spectral analysis of electrospray ionization mass spectroscopy (ESI-MS), one-dimensional nuclear magnetic resonance spectroscopy (1D-NMR) and two-dimensional-nuclear magnetic resonance spectroscopy (2D-NMR) including ${ }^{1} \mathrm{H}-\mathrm{NMR},{ }^{13} \mathrm{C}-\mathrm{NMR}$, distortionless enhancement by polarization transfer (DEPT) and heteronuclear multiple bond coherence (HMBC), and singlecrystal X-ray diffraction techniques.

Key words Selaginella tamariscina; selaginellin A; selaginellin B

Selaginella tamariscina (BEAUv.) SPRING is a Chinese herbal medicine, that is widely distributed in China. There is a long history of using the whole herbs of S. tamariscina in traditional Chinese medicines, and there has been much pharmacology research on Selaginella species. ${ }^{1-3)}$ Previous phytochemical studies on the constituents of genus $\mathrm{Se}$ laginella led to the discovery of many compounds, including biflavonoids, ${ }^{4-8)}$ lignan, ${ }^{8)}$ lignanoside, ${ }^{9)}$ alkaloids, ${ }^{10,11)}$ etc. A natural pigment named selaginellin was isolated from $\mathrm{Se}$ laginella sinensis recently. ${ }^{12)}$ In the course of our studies on $S$. tamariscina, we examined the constituents of the ethanol extract of whole herbs of this species. We have isolated and elucidated two new natural pigments, selaginellin A (1) and selaginellin B (2), along with four known biflavonoids, amentoflavone (3), hinokiflavone (4), heveaflavone (5), and 7"-O-methylamentoflavone (6). The structures of these compounds were assayed by extensive spectral analysis including 2D-NMR and HR-MS spectra. We report herein the isolation and structure elucidation of two new unusual natural pigments, selaginellin A (1) and seleginellin B (2).

\section{Results and Discussion}

The EtOH extract of the whole herbs of $S$. tamariscina was concentrated and partitioned with chloroform and ethyl acetate. The ethyl acetate fraction was separated by a combination of chromatographies such as silica gel column chromatography, Sephadex LH-20 column chromatography, preparative thin-layer chromatography, and preparative highperformance liquid chromatography to yield two new compounds: selaginellin A (1) and selaginellin B (2), and four known biflavonoids. They were identified as amentoflavone $(3),{ }^{13)}$ hinokiflavone (4), ${ }^{13)}$ heveaflavone $(5),{ }^{8)}$ and $7^{\prime \prime}-O$ methyl amentoflavone $(\mathbf{6})^{14)}$ based on comparison of their physical and spectral data with literature values. The structures of compounds $\mathbf{1}-\mathbf{6}$ are shown in Fig. 1.

Selaginellin A (1) was obtained as red needle crystal. The molecular formula of 1 was determined to be $\mathrm{C}_{33} \mathrm{H}_{23} \mathrm{O}_{4}$, by HR-ESI-MS at $m / z$ 483.15957, with the degree of unsaturation being 23 . The melting point was $189-190^{\circ} \mathrm{C}$. UV $\lambda_{\max }^{\mathrm{MeOH}} \mathrm{nm}(\log \varepsilon): 297(3.15), 430$ (3.27). IR $v^{\mathrm{KBr}}, \mathrm{cm}^{-1}$ : $1595,1511,1456$, indicated the presence of a benzene ring. The ${ }^{1} \mathrm{H}-\mathrm{NMR}$ (Table 1) spectrum showed that all hydrogen is aromatic protons. Three proton spin systems, including four para-benzene moieties [H-29, $31\left(\delta_{\mathrm{H}} 6.56,2 \mathrm{H}, \mathrm{d}, J=8.5 \mathrm{~Hz}\right)$ and $\mathrm{H}-28,32\left(\delta_{\mathrm{H}} 6.91,2 \mathrm{H}, \mathrm{d}, J=8.5 \mathrm{~Hz}\right), \mathrm{H}-8,12\left(\delta_{\mathrm{H}} 7.08\right.$, $2 \mathrm{H}, \mathrm{d}, J=9.0 \mathrm{~Hz})$ and $\mathrm{H}-9,11\left(\delta_{\mathrm{H}} 6.47,2 \mathrm{H}, \mathrm{d}, J=9.0 \mathrm{~Hz}\right), \mathrm{H}-$ $20,24\left(\delta_{\mathrm{H}} 6.72,2 \mathrm{H}, \mathrm{d}, J=8.5 \mathrm{~Hz}\right)$ and $\mathrm{H}-21,23\left(\delta_{\mathrm{H}} 6.48\right.$, $2 \mathrm{H}, \mathrm{d}, J=8.5 \mathrm{~Hz})]$, were identified by ${ }^{1} \mathrm{H}-{ }^{1} \mathrm{H}$ correlation spectroscopy $\left({ }^{1} \mathrm{H}-{ }^{1} \mathrm{H}\right.$ COSY), and one hemi-benzene moiety
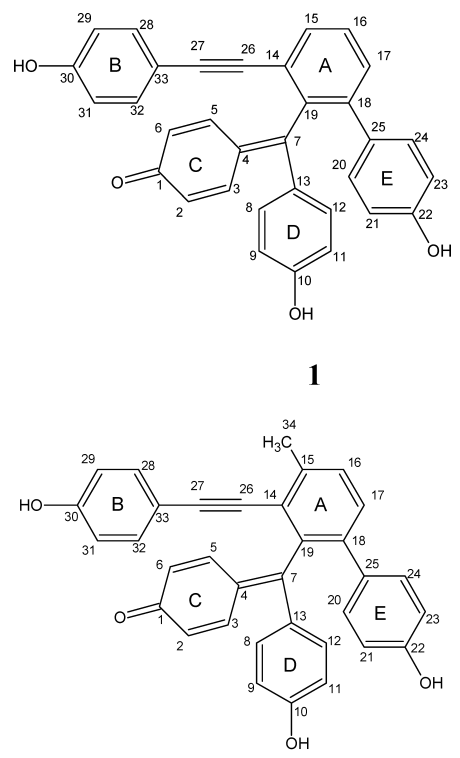

2

Fig. 1. Structures of Isolated Compounds $\mathbf{1}$ and $\mathbf{2}$ 
Table 1. ${ }^{1} \mathrm{H}-,{ }^{13} \mathrm{C}-\mathrm{NMR}$ Data of Compound 1 at $500 \mathrm{MHz}$ (for ${ }^{1} \mathrm{H}-\mathrm{NMR}$ ) and $125 \mathrm{MHz}$ (for ${ }^{13} \mathrm{C}-\mathrm{NMR}$ ) and HMBC Data

\begin{tabular}{|c|c|c|c|}
\hline & ${ }^{13} \mathrm{C}-\mathrm{NMR}$ & ${ }^{1} \mathrm{H}-\mathrm{NMR}$ & $\mathrm{HMBC}(\mathrm{H} \rightarrow \mathrm{C})$ \\
\hline 1 & 165.6 & & \\
\hline 2,6 & 122.3 & $6.47(2 \mathrm{H}, \mathrm{d}, J=9.0 \mathrm{~Hz})$ & $\mathrm{C} 4$ \\
\hline 3,5 & 138.9 & $7.08(2 \mathrm{H}, \mathrm{d}, J=9.0 \mathrm{~Hz})$ & $\mathrm{C} 1$ \\
\hline 4 & 131.4 & & \\
\hline 7 & 133.0 & & \\
\hline 8,12 & 138.9 & $7.08(2 \mathrm{H}, \mathrm{d}, J=9.0 \mathrm{~Hz})$ & $\mathrm{C} 10$ \\
\hline 9,11 & 122.3 & $6.47(2 \mathrm{H}, \mathrm{d}, J=9.0 \mathrm{~Hz})$ & C13 \\
\hline 10 & 165.6 & & \\
\hline 13 & 131.4 & & \\
\hline 14 & 126.4 & & \\
\hline 15 & 131.4 & $7.55(1 \mathrm{H}, \mathrm{d}, J=8.0 \mathrm{~Hz})$ & $\mathrm{C} 19, \mathrm{C} 17, \mathrm{C} 26$ \\
\hline 16 & 130.6 & $7.45(1 \mathrm{H}, \mathrm{m})$ & $\mathrm{C} 14, \mathrm{C} 18$ \\
\hline 17 & 131.0 & $7.26(1 \mathrm{H}, \mathrm{d}, J=8.0 \mathrm{~Hz})$ & $\mathrm{C} 19, \mathrm{C} 15$ \\
\hline 18 & 145.0 & & \\
\hline 19 & 142.3 & & \\
\hline 20,24 & 131.0 & $6.72(2 \mathrm{H}, \mathrm{d}, J=8.5 \mathrm{~Hz})$ & $\mathrm{C} 22, \mathrm{C} 18, \mathrm{C} 17$ \\
\hline 21,23 & 115.7 & $6.48(2 \mathrm{H}, \mathrm{d}, J=8.5 \mathrm{~Hz})$ & $\mathrm{C} 25, \mathrm{C} 22$ \\
\hline 22 & 158.0 & & \\
\hline 25 & 115.7 & & \\
\hline 26 & 87.2 & & \\
\hline 27 & 95.2 & & \\
\hline 28,32 & 134.1 & $6.91(2 \mathrm{H}, \mathrm{d}, J=8.5 \mathrm{~Hz})$ & $\mathrm{C} 27, \mathrm{C} 30$ \\
\hline 29,31 & 116.4 & $6.56(2 \mathrm{H}, \mathrm{d}, J=8.5 \mathrm{~Hz})$ & $\mathrm{C} 33, \mathrm{C} 30$ \\
\hline 30 & 159.4 & & \\
\hline 33 & 114.6 & & \\
\hline
\end{tabular}

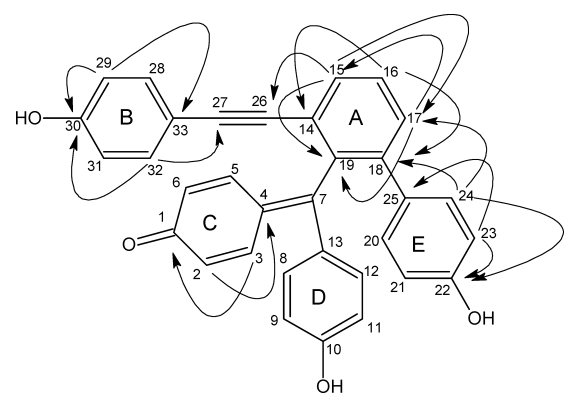

Fig. 2. Selected HMBC Correlation for Compound $\mathbf{1}$

due to $\mathrm{H}-17\left(\delta_{\mathrm{H}} 7.55\right)$ and $\mathrm{H}-16(\delta 7.45), \mathrm{H}-15(\delta 7.26)$ were the consecutive protons in the same benzene ring. The chemical shifts and the coupling constants of these proton spin systems showed that 1 contained five benzene rings. The ${ }^{13} \mathrm{C}$ NMR spectrum (Table 1) contained 19 signals, that could be classified using the DEPT data as nine methylenes and ten quaternary carbons, and revealed the presence of a symmetrical unit in the structure. $\delta_{\mathrm{C}} 95.2$ and $\delta_{\mathrm{C}} 87.2$ showed the presence of an acetylene bond. The total degree of unsaturation of five benzene rings and one acetylene was 22 , which did not agree with the degree of unsaturation being 23 , so there must be one double bond in the structure of compound 1.

The proton-carbon connectivity of $\mathbf{1}$ was determined by HMQC experiments. The connectivity of the five benzene rings and one acetylene bond of compound $\mathbf{1}$ was determined by the heteronuclear multiple-bond correlation spectroscopy (HMBC) (Fig. 2). In the HMBC spectrum of compound $\mathbf{1}$, correlation peaks were observed between $\mathrm{H}-28,32\left(\delta_{\mathrm{H}} 6.91\right)$ and $\mathrm{C}-27\left(\delta_{\mathrm{C}} 95.2\right), \mathrm{C}-30\left(\delta_{\mathrm{C}} 159.4\right)$, also between $\mathrm{H}-15\left(\delta_{\mathrm{H}}\right.$ $7.55)$ and $\mathrm{C}-19\left(\delta_{\mathrm{C}} 142.3\right), \mathrm{C}-17\left(\delta_{\mathrm{C}} 131.0\right), \mathrm{C}-26\left(\delta_{\mathrm{C}} 87.2\right)$,
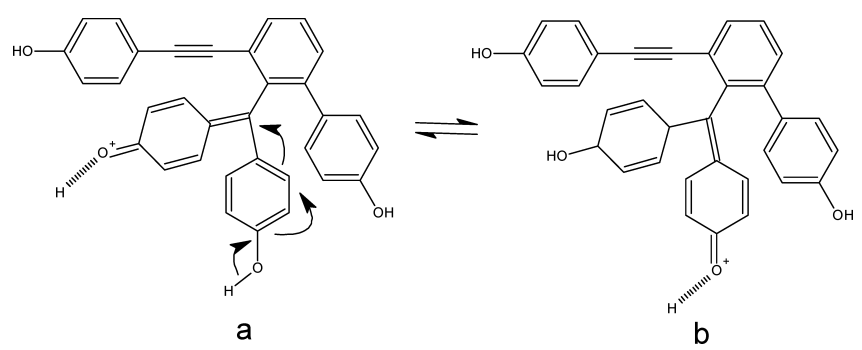

Fig. 3. The Tautomerism of Compound $\mathbf{1}$

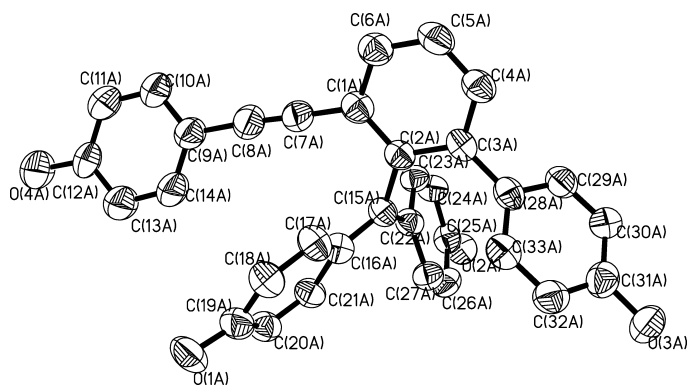

Fig. 4. Stereoview of Compound $\mathbf{1}$ from X-Ray Crystallographic Analysis

$\mathrm{H}-20,24\left(\delta_{\mathrm{H}} 6.72\right)$ and $\mathrm{C}-18\left(\delta_{\mathrm{C}} 145.0\right), \mathrm{C}-17\left(\delta_{\mathrm{C}} 131.0\right), \mathrm{C}-$ $22\left(\delta_{\mathrm{C}} 158.0\right)$. Moreover, $\mathrm{H}-17\left(\delta_{\mathrm{H}} 7.26\right)$ and $\mathrm{C}-19\left(\delta_{\mathrm{C}}\right.$ $142.3), \mathrm{C}-15\left(\delta_{\mathrm{C}} 131.4\right), \mathrm{H}-16\left(\delta_{\mathrm{H}} 7.45\right)$ and $\mathrm{C}-14\left(\delta_{\mathrm{C}}\right.$ $126.4), \mathrm{C}-18\left(\delta_{\mathrm{C}} 145.0\right), \mathrm{H}-29,31\left(\delta_{\mathrm{H}} 6.56\right)$ and $\mathrm{C}-33\left(\delta_{\mathrm{C}}\right.$ $114.6), \mathrm{C}-30\left(\delta_{\mathrm{C}} 159.4\right)$. Thus the structure of compound 1 was established to be selaginellin A, $(R, S)-4-\left[\left(4^{\prime}\right.\right.$-hydroxy-3((4-hydroxyphenyl)ethynyl)biphenyl-2-yl)(4-hydroxyphenyl)methylene]-2,5-cyclohexadien-1-one.

The chemical shift of ${ }^{1} \mathrm{H}-\mathrm{NMR}$ and ${ }^{13} \mathrm{C}-\mathrm{NMR}$ of $\mathrm{C}$ benzene ring and $\mathrm{D}$ benzene ring of $\mathbf{1}$ are similar which does not agree with the structure of selaginellin $\mathrm{A}$, and the ${ }^{1} \mathrm{H}-\mathrm{NMR}$ and ${ }^{13} \mathrm{C}$-NMR of selaginellin $\mathrm{A}$ in $\mathrm{CD}_{3} \mathrm{OD}$ is quite different from those of selaginellin in $\mathrm{CD}_{3} \mathrm{COCD}_{3}$ as previously published. ${ }^{12)}$ This observation may have been caused by the tautomerism of $\mathrm{a}$ and $\mathrm{b}$ with the contribution of active hydrogen (Fig. 3). ${ }^{12)}$

The relative stereochemistry of compound $\mathbf{1}$ was deduced from X-ray crystallography. A view of the solid state conformation is provided in Fig. 4. Bond distances and bond angles are provided in Table 2 .

Selaginellin B (2) was obtained as red needle crystal. The molecular formula of 2 was determined to be $\mathrm{C}_{34} \mathrm{H}_{25} \mathrm{O}_{4}$, by HR-ESI-MS at $m / z$ 497.17419, with the degree of unsaturation being 23 . The melting point was $190-191^{\circ} \mathrm{C}$; UV $\lambda_{\max }^{\mathrm{MeOH}} \mathrm{nm}(\log \varepsilon): 300(3.18), 431$ (3.21). IR $v^{\mathrm{KBr}}, \mathrm{cm}^{-1}$ : $1597,1512,1488,1449$, indicated the presence of a benzene ring. The IR spectrum of compound 2 agreed with that of compound 1 . The ${ }^{1} \mathrm{H}$ - and ${ }^{13} \mathrm{C}-\mathrm{NMR}$ (Table 2) of compound $\mathbf{2}$ were closely similar to those of compound $\mathbf{1}$ except for the appearance of a methyl group proton $\left[\delta_{\mathrm{H}} 2.54(3 \mathrm{H}, \mathrm{s})\right]$ attached to the carbon $\left(\delta_{\mathrm{C}} 21.2\right)$ in compound 2 . The HMBC spectrum revealed correlation peaks between $\mathrm{H}-33$ of $15-$ $\mathrm{CH}_{3}\left(\delta_{\mathrm{H}} 3.25\right)$ and $\mathrm{C}-26\left(\delta_{\mathrm{C}} 86.0\right), \mathrm{C}-19\left(\delta_{\mathrm{C}} 139.9\right), \mathrm{C}-14$ $\left(\delta_{\mathrm{C}} 125.8\right), \mathrm{C}-16\left(\delta_{\mathrm{C}} 130.6\right)$, which confirmed the substitution of methyl at $\mathrm{C}-15$ position (Fig. 5). Thus, the structure of compound 2 was established to be selaginellin $\mathrm{B},(R, S)-4$ [(4'-methoxy-4-(methyl)-3-((4-methoxyphenyl)ethynyl)- 
Table 2. ${ }^{1} \mathrm{H}-,{ }^{13} \mathrm{C}-\mathrm{NMR}$ Data of Compound 2 at $500 \mathrm{MHz}$ (for ${ }^{1} \mathrm{H}-\mathrm{NMR}$ ) and $125 \mathrm{MHz}$ (for ${ }^{13} \mathrm{C}-\mathrm{NMR}$ ) and $\mathrm{HMBC}$ Data

\begin{tabular}{|c|c|c|c|}
\hline & ${ }^{13} \mathrm{C}-\mathrm{NMR}$ & ${ }^{1} \mathrm{H}-\mathrm{NMR}$ & $\mathrm{HMBC}(\mathrm{H} \rightarrow \mathrm{C})$ \\
\hline 1 & 166.5 & & \\
\hline 2,6 & 122.2 & $6.46(2 \mathrm{H}, \mathrm{d}, J=9.0 \mathrm{~Hz})$ & $\mathrm{C} 4$ \\
\hline 3,5 & 139.0 & $7.09(2 \mathrm{H}, \mathrm{d}, J=9.0 \mathrm{~Hz})$ & $\mathrm{C} 1$ \\
\hline 4 & 131.6 & & \\
\hline 7 & 133.1 & & \\
\hline 8,12 & 139.0 & $7.09(2 \mathrm{H}, \mathrm{d}, J=9.0 \mathrm{~Hz})$ & $\mathrm{C} 10$ \\
\hline 9,11 & 122.2 & $6.46(2 \mathrm{H}, \mathrm{d}, J=9.0 \mathrm{~Hz})$ & $\mathrm{C} 13$ \\
\hline 10 & 166.5 & & \\
\hline 13 & 131.6 & & \\
\hline 14 & 125.8 & & \\
\hline 15 & 131.3 & & \\
\hline 16 & 130.6 & $7.37(1 \mathrm{H}, \mathrm{d}, J=8.0 \mathrm{~Hz})$ & $\mathrm{C} 14, \mathrm{C} 18$ \\
\hline 17 & 131.6 & $7.15(1 \mathrm{H}, \mathrm{d}, J=8.0 \mathrm{~Hz})$ & $\mathrm{C} 19, \mathrm{C} 18, \mathrm{C} 15$ \\
\hline 18 & 142.2 & & \\
\hline 19 & 139.9 & & \\
\hline 20,24 & 131.3 & $6.71(2 \mathrm{H}, \mathrm{d}, J=8.5 \mathrm{~Hz})$ & $\mathrm{C} 22, \mathrm{C} 18, \mathrm{C} 17$ \\
\hline 21,23 & 115.7 & $6.48(2 \mathrm{H}, \mathrm{d}, J=8.5 \mathrm{~Hz})$ & $\mathrm{C} 25, \mathrm{C} 22$ \\
\hline 22 & 157.8 & & \\
\hline 25 & 115.7 & & \\
\hline 26 & 86.0 & & \\
\hline 27 & 100.0 & & \\
\hline 28,32 & 133.9 & $6.91(2 \mathrm{H}, \mathrm{d}, J=8.5 \mathrm{~Hz})$ & $\mathrm{C} 27, \mathrm{C} 30$ \\
\hline 29,31 & 116.4 & $6.53(2 \mathrm{H}, \mathrm{d}, J=8.5 \mathrm{~Hz})$ & $\mathrm{C} 33, \mathrm{C} 30$ \\
\hline 30 & 159.3 & & \\
\hline 33 & 114.8 & & \\
\hline $34\left(15-\mathrm{CH}_{3}\right)$ & 21.2 & $2.54(3 \mathrm{H}, \mathrm{s})$ & $\mathrm{C} 26, \mathrm{C} 19, \mathrm{C} 14, \mathrm{C} 16$ \\
\hline
\end{tabular}

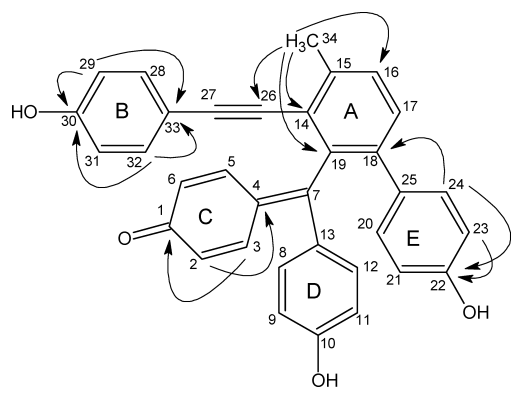

Fig. 5. Selected HMBC Correlation for Compound 2

biphenyl-2-yl)(4-methoxyphenyl)methylene]-2,5-cyclohexadien-1-one.

\section{Experimental}

General Experimental Procedures All melting points were determined by Kofle instrument and were uncorrected. UV spectra were recorded by Agilent 8453 spectrophotometer. IR absorption spectra were obtained with Nicolet Impact 400 FT-IR instrument as a film on $\mathrm{KBr}$ disk. ${ }^{1} \mathrm{H}$ and ${ }^{13} \mathrm{C}$ spectra were obtained with INOVA-500 instrument. Chemical shifts were reported in parts per million on the $\delta$ scale with TMS as internal standard, and coupling constants were in Hertz. Single-crystal X-diffraction analysis was measured on a MAC DIP-2030K diffractometer; HR-ESI-MS was recorded on JMS-T100CS system. Column chromatography was performed with silica gel and Sephadex LH-20. TLC was performed on precoated Silica plates with $\mathrm{CHCl}_{3}-\mathrm{MeOH}$ system and spots were detected by vis illumination. Wa- ters Prep LC 4000 System was used for preparing compound 1 with 2487 detector.

Plant Material The whole herbs of $S$. tamariscina were collected in Beijing, P. R. China, in October 2005. A voucher specimen (ST-01-2005) was deposited at the Museum for Materia Medica, National Institute for the Control of Pharmaceutical and Biological Products, Beijing.

Extraction and Isolation Whole herbs of $S$. tamariscina $(15 \mathrm{~kg})$ were ground to a coarse powder and extracted with $95 \%$ ethanol $(101 \times 3)$. The ethanol extract was evaporated in vacuo to yield a dark residue $(352 \mathrm{~g})$. The ethanol extract was re-extracted with chloroform and ethyl acetate. The ethyl acetate extract $(43 \mathrm{~g})$ was chromatographed on silica gel column $(10 \times 70 \mathrm{~cm})$ with chloroform-methanol gradient system to yield 4 fractions. Frs. 2 and 3 were chromatographed by Sephadex LH-20 and PTLC to afford amentoflavone $(3,100 \mathrm{mg})$, hinokiflavone $(4,21 \mathrm{mg})$, heveaflavone $(5$, $14 \mathrm{mg})$, and $7^{\prime}-O$-methylamentoflavone $(6,19 \mathrm{mg})$. Fr. 4 was chromatographed by Sephadex LH-20 and prepared HPLC to yield selaginellin A $(\mathbf{1}, 25 \mathrm{mg})$ and selaginellin $\mathrm{B}(\mathbf{2}, 18 \mathrm{mg})$.

Selaginellin A (1): Red needle crystal, mp $191-192^{\circ} \mathrm{C}$. UV $\lambda_{\max }^{\mathrm{MeOH}} \mathrm{nm}$ ( $\log \varepsilon): 297$ (3.15), 430 (3.27); IR $v^{\mathrm{KBr}}, \mathrm{cm}^{-1}: 3150,2799,2669,1595$, $1511,1456,1377,1336,1241,1162,902,836$; HR-ESI-MS $m / z: 483.15957$ (Calcd for $\left.\mathrm{C}_{33} \mathrm{H}_{23} \mathrm{O}_{4}: 483.15960\right) ;{ }^{1} \mathrm{H}$ - and ${ }^{13} \mathrm{C}-\mathrm{NMR}$ data of $\mathbf{1}$ are shown in Table 1. Crystal size: $0.40 \times 1.00 \times 3.00 \mathrm{~mm}$; crystal system: triclinic system; space group: P-1; unit cell parameters: $a=10.188$ (1), $b=17.987$ (4), $c=20.614$ (4) $\AA, V=3381.7$ (3) $\AA^{3}, Z=2, D_{\text {calcd }}=1.087 \mathrm{~g} / \mathrm{cm}^{3}$. The diffraction data were collected by MAC DIP-2030K Imaging Plate diffractometer with MoK $\alpha$ Radiation, $2 \theta_{\max } 50.0^{\circ}, 7747$ independent reflections, observed 6361 were used for refinement. The structure was solved by direct method and refinement by the full matric least square methods, the final $R f=0.0748$, $R w_{\mathrm{w}}=0.1968\left(w=1 / \sigma|F|^{2}\right)$. The Cambridge Crystallographic Data Centre (CCDC) deposition number is 679453 .

Selaginellin B (2): Red needle crystal, mp 190-191 ${ }^{\circ} \mathrm{C}$. UV $\lambda_{\max }^{\mathrm{MeOH}} \mathrm{nm}$ $(\log \varepsilon): 300$ (3.18), 431 (3.21); IR $v^{\mathrm{KBr}}, \mathrm{cm}^{-1}: 3133,2800,2669,1597$, $1488,1448,1377,1336,1264,1164,911,834$; HR-ESI-MS $m / z: 497.17419$ (Calcd for $\mathrm{C}_{34} \mathrm{H}_{25} \mathrm{O}_{4}: 497.17528$ ); ${ }^{1} \mathrm{H}$ - and ${ }^{13} \mathrm{C}-\mathrm{NMR}$ data of 2 are shown in Table 2.

\section{References}

1) Yang S. F., Chu S. C., Liu S. J., Chen Y. C., Chang Y. Z., Hsieh Y. S., J. Ethnopharmacol., 110, 483-489 (2007).

2) Ahn S. H., Mun Y. J., Lee S. W., Kwak S., Choi M. K., Baik S. K., Kim Y. M., Woo W. H., J. Med. Food, 9, 138-144 (2006).

3) Dai Y., But P. P. H., Chu L. M., Chan Y. P., Am. J. Chin. Med., 33, 957-966 (2005).

4) Sun C. M., Syu W. J., Huang Y. T., Chen C. C., Ou J. C., J. Nat. Prod., 60, 382-384 (1997).

5) Silva G. L., Chai H., Gupta M. P., Farnsworth N. R., Cordell G. A., Pezzuto J. M., Beecher C. W., Kinghorn A. D., Phytochemistry, 4, 129-134 (1995)

6) Chen J. J., Duh C. Y., Chen J. F., Planta Med., 71, 659-665 (2005).

7) Lin L. C., Kuo Y. C., Chou C. J., J. Nat. Prod., 63, 627-630 (2000).

8) Lin R. C., Skaltsounis A. L., Seguin E., Tillequin F., Koch M., Planta Med., 60, 168-170 (1994).

9) Lin R. C., Seluin E., Skaltsounis A. L., Tillequin F., Koch M., J. Nat. Prod., 53, 882-893 (1990).

10) Zheng X. K., Shi S. P., Bi Y. F., Feng W. S., Wang J. F., Niu J. Z., Yao Хие Xиe Bao, 39, 719-721 (2004).

11) Lin R. C., Seguin E., Tiliequin F., J. Nat. Prod., 50, 422-426 (1987).

12) Zhang L. P., Liang Y. M., Wei X. C., Cheng D. L., J. Org. Chem., 72, 3921-3924 (2007).

13) Markham K. R., Sheppard C., Geiger H., Phytochemistry, 26, 33353337 (1987).

14) Ma S. C., But P. P. H., Ooi E. C., He Y. H., Lee S. H. S., Lee S. F., Lin R. C., Biol. Pharm. Bull., 24, 311-312 (2001). 